\title{
TOURMALINE AS AN INCLUSION IN ZAMBIAN EMERALDS
}

\author{
By John I. Koivula
}

This article reports the identification of tourmaline crystals as inclusions in emeralds from Zambia, in south-central Africa. To understand the paragenesis responsible for this unusual association, the geology of the area is reviewed. The gemological properties of these emeralds are also noted.

To date, a variety of interesting mineral inclusions have been reported in the emeralds from the deposits at Miku-Kafubu, in Zambia (Sinkankas, 1981). These include the micas biotite and phlogopite, rutile, and apatite. Recently, the author had the opportunity to study three rough emeralds and one faceted stone from this locality with inclusions that appeared to be tourmaline, a mineral that has been reported as inclusions in emeralds from the Urals in the Soviet Union and from the Habachtal mine in Austria (Sinkankas, 1981; Gübelin, 1974) but has not previously been noted as occurring in Zambian emeralds.

If the inclusions the author observed are in fact tourmaline, then a new paragenetic relationship could be established and a new species added to the list of known inclusions in Zambian emeralds. To this end, the geology of the area is reviewed and the inclusions themselves described in detail. Also, the gemological properties of these stones are compared to those previously reported for Zambian emeralds.

\section{GENERAL GEOLOGY OF THE ZAMBIAN EMERALD AREA}

The main emerald-producing area in Zambia comprises two deposits, Miku and Kafubu, which lie within a few kilometers of each other. This emerald field is located in the Kitwe district of northern Zambia, approximately $32 \mathrm{~km}$ southwest of Kitwe and $40 \mathrm{~km}$ west-northwest of Luanshya, near the entrance of the Miku River into the Kafubu River (Bank, 1974). Both Miku and Kafubu produce excellent, gem-quality emeralds; some crystals weigh well over $100 \mathrm{ct}$.
The two deposits are geologically similar. The emeralds are found in biotite-phlogopite schists in which dark brown to black tourmaline also occurs. Other rocks intimately associated with the emerald- and tourmaline-bearing mica schists are talc-magnetite schists and quartz-amphibolite-chlorite schists with secondary quartz veining (Bank, 1974; Sinkankas, 1981). It is thought that the chromium necessary to provide the traceelemental coloration of the emerald was derived from magnetite in the talc-magnetite schists, as the magnetite in these rocks has been shown to contain a small percentage of chromium (Bank, 1974).

\section{TOURMALINE AS AN INCLUSION}

Because tourmaline is found throughout the schist host rock in direct association with the emeralds, it is not surprising to find tourmaline crystals as inclusions in the emeralds. The inclusions observed in the four specimens studied by the author are prismatic and, as is typical of tourmalines, striated parallel to the c-axis (see figure 1). They are transparent dark orangy brown in a strong transmitted light or on very thin edges, but generally they appear black and opaque. They occur up to $10 \mathrm{~mm}$ in length and $2 \mathrm{~mm}$ in diameter. Many are easily seen with the naked eye.

Surrounding the tourmalines are numerous tiny, whitish-appearing tension fractures that extend into the host emerald. Some of these, as illustrated in figure 1, are decorated with brownish

\footnotetext{
ABOUT THE AUTHOR

Mr. Koivula is the senior staff gemologist in the Gem Identification Department of the Gem Trade Laboratory, Inc., Santa Monica, California.

Acknowledgments: The author would like to express his sincere thanks to Julius Pelsch for donating the emeralds with tourmaline inclusions for this study, and to Peter Keller for arranging the donation. A special thanks goes to Chuck Fryer for the X-ray diffraction work, to Roger Kuchek for his assistance in obtaining the ColorMaster notations, to Stephen Hofer for his consultation on the absorption spectra, and to William Kerr for faceting the large stone used in this study.

1983 Gemological Institute of America
} 


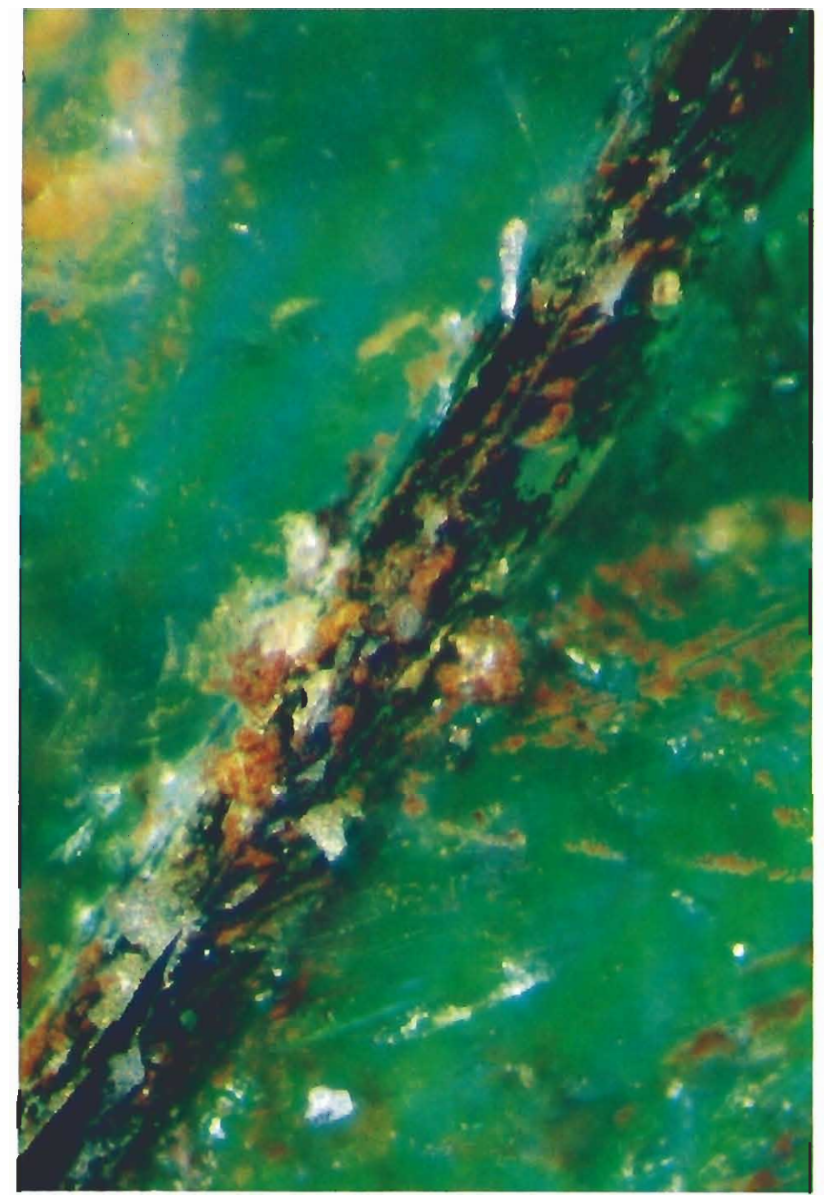

Figure 1. A black-appearing crystal of dravite tourmaline in a Zambian emerald is decorated by numerous small tension fractures, some of which are stained by limonite. This photomicrograph was taken using a combination of low-intensity transmitted light and oblique illumination, magnified $20 \times$.

orange limonite. In cross section, as in figure 2, the tourmalines display typical trigonal or triangular outlines. No crystallographically dictated alignment was noted between the tourmaline inclusions and their host.

Noted gemologist Chuck Fryer scraped one of the inclusions that reached the surface and obtained enough powder for X-ray diffraction analysis. The inclusion was found to correspond to tourmaline in the schorl-dravite series, schorl having the chemical composition $\mathrm{Na}(\mathrm{Fe}, \mathrm{Mn})_{3} \mathrm{Al}_{6} \mathrm{~B}_{3}$ $\mathrm{Si}_{6} \mathrm{O}_{27}(\mathrm{OH}, \mathrm{F})_{4}$ and dravite, $\mathrm{NaMg}_{3} \mathrm{Al}_{6} \mathrm{~B}_{3} \mathrm{Si}_{6} \mathrm{O}_{27}(\mathrm{OH}, \mathrm{F})_{4}$. The diffraction pattern obtained matched dravite more closely than schorl, but a detailed chemical analysis would be necessary to conclusively place these tourmalines in their proper position in the schorl-dravite series.

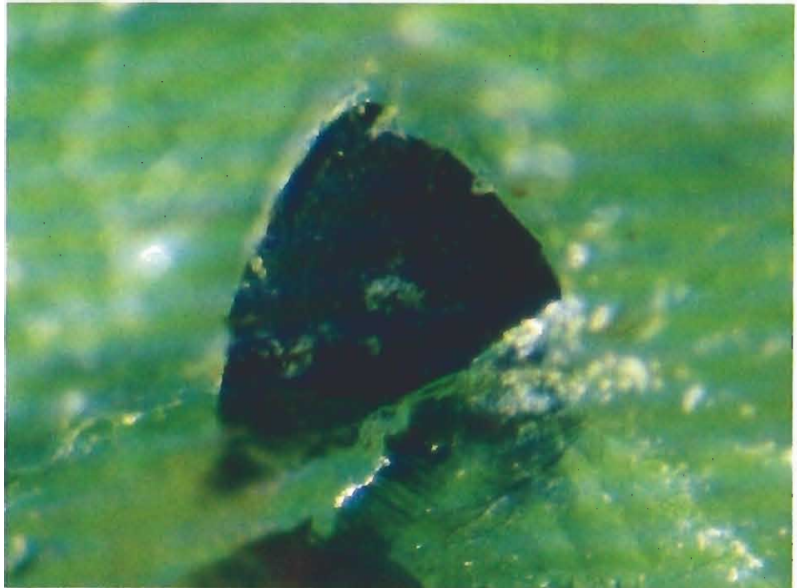

Figure 2. Cross-sectional view of one of the dravite tourmaline inclusions breaking the surface of a rough crystal of Zambian emerald. Oblique illumination, magnified $50 \times$.

\section{GEMOLOGICAL PROPERTIES}

One faceted and three rough emeralds were examined. The faceted stone was an emerald cut that weighed $0.91 \mathrm{ct}$, and the largest rough crystal section weighed $3.48 \mathrm{ct}$. The emeralds varied in color from a bluish green of medium intensity to a dark, intense bluish green.

Using the GEM ColorMaster, the color of the 0.91 -ct faceted stone was dialed in as 00 red, 43 green, and 22 blue using the E modifier. This reading calculated as $0.230 \mathrm{x}, 0.586 \mathrm{y}$, and $5.72 \mathrm{z}$ for the coordinates on the CIE color chart, giving a very slight bluish green by CIE standards.

Refractive index and optic character were determined using a Duplex II refractometer and a sodium vapor light source. Refractive indices of $\epsilon=1.581$ and $\omega=1.588$ were noted, which gives an optic character and sign of uniaxial negative and a birefringence of 0.007 .

The emeralds were studied for their visible light absorption characteristics using a Beck wavelength prism spectroscope and the GEM spectroscope unit. In the direction of the ordinary ray, parallel to the c-axis, sharp absorption lines could be seen at approximately $479 \mathrm{~nm}, 610 \mathrm{~nm}$, $638 \mathrm{~nm}$, and $670 \mathrm{~nm}$, with a single, somewhat thicker band at approximately $682 \mathrm{~nm}$.

A general absorption band was also noted between $580 \mathrm{~nm}$ and $610 \mathrm{~nm}$. At $90^{\circ}$ from the c-axis, only four distinct absorption lines were observed: $638 \mathrm{~nm}, 650 \mathrm{~nm}, 670 \mathrm{~nm}$, and $690 \mathrm{~nm}$. All of the absorption points in these emeralds can be correlated to known chromium absorption peaks (Sinkankas, 1981). 
The emeralds showed no reaction to longwave or short-wave ultraviolet radiation, or to $\mathrm{X}$-radiation.

The specific gravity was hydrostatically determined for two of the emerald specimens. One specimen, devoid of tourmaline and containing only a small number of mica platelets, showed an average specific gravity reading of 2.71 . The second specimen, shot through with numerous tourmaline crystals as well as with mica and other assorted inclusions, revealed a specific gravity of 2.82. This higher S.G. could be due in part to the presence of the schorl-dravite tourmaline, which has a specific gravity $(3.03-3.25)$ that is much higher than that of emerald. The gemological properties obtained by the author for refractive index and specific gravity (on the less included stone) were in close agreement with those published by Bank (1974) for emeralds from Miku, Zambia.

\section{CONCLUSION}

Although tourmaline has been reported as inclusions in emeralds from the Ural Mountains in the Soviet Union and from the Habachtal emerald mine in Austria, this is the first report of such inclusions in African emeralds. Since emerald has not yet been found included in Zambian tourmalines, it can be inferred that the emeralds may be geologically younger than the tourmalines.

In reviewing the suite of inclusions now known to occur in Zambian emeralds, we find striking similarities to inclusions in emeralds from other schist-type deposits. In fact, the emeralds from the mica schist in Habachtal, Austria (Gübelin, 1956, 1974l, are known to play host to all of the minerals so far found as inclusions in Zambian emeralds. Such comparable parageneses support the view that schist-type emeralds all undergo similar stages of genesis.

Editor's note: An attractive example of a faceted Zambian emerald is illustrated in the Gem Trade Lab Notes section of this issue.

\section{REFERENCES}

Bank H. (1974) The emerald occurrence of Miku, Zambia. Journal of Gemmology, Vol. 14, No. 1, pp. 8-15.

Guibelin E.J. (1956) The emerald from Habachtal. Gems \&) Gemology, Vol. 8, No. 10, pp. 295-309.

Gubelin E.J. (1974) Internal World of Gemstones. ABC edition, Zurich, Switzerland.

Sinkankas I. (1981) Emerald and Other Beryls. Chilton Book Co., Radnor, PA.

\section{SECOND ANNUAL GEMS \& GEMOLOGY MOST VALUABLE ARTICLE AWARD}

This issue marks the end of the 1982 volume year of Cems \& Cemology. Once again, we are asking you-our readersto select the three articles that you found most interesting and potentially useful. By participating in this ballot, you not only help us acknowledge the time and effort that these authors have contributed to expanding the gemological literature, but you also give us a better idea of your needs and interests.

Your ballot is located on the insert card inside this issue. Please choose three articles from 1982 and mark them in order of numerical preference: (1) first, (2) second, (3) third. Be sure to mark only three articles for the entire year. Additional comments concerning the journal are welcome in the space provided. After voting, simply detach the postcard ballot and drop it in the mail (postage pre-paid if mailed in the U.S.). Ballots must be received by March 15, 1983 to be included in the final tally.

The winning articles will be announced in the Spring 1983 issue of Cems \& Cemology, with cash awards of $\$ 500, \$ 300$, and $\$ 100$, respectively, given to the authors of the three most valuable articles.

Your participation is important to the vitality of the journal. So please take just a few minutes now to let us know how you feel, and help honor the authors whose work has educated and enlightened gemological readers around the world.

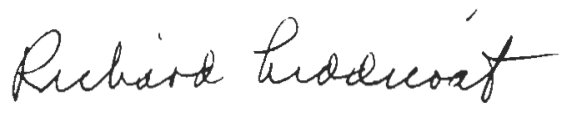

